\title{
The Never Ending Fight; Court Ordered Parenting Plan
}

\author{
Anyogu, Felicia \\ Faculty of Law \\ Nnamdi Azikiwe University \\ Awka Anambra State, Nigeria
}

$\&$

\author{
Okpalaobi, B. Nkechi \\ Faculty of Law \\ Nnamdi Azikiwe University \\ Awka Anambra State, Nigeria \\ E-mail:nklobi@yahoo.com
}

\begin{abstract}
The question as to who retains the custody, physical control and care of the child or children of a marriage is often cardinal, vexed and contentious between the parties in any court proceedings for dissolution of marriage, divorce or legal separation .This paper examines the legal principles, perspectives and dimensions relative to court ordered parenting in Nigeria with particular attention to the comparative positions at common law, under statute and within the realm of customary law. It also x-rays the sociological and psychological considerations and factors at play in such proceedings especially as it relates to the part of the parting, contending parties and as they influence the decision of the court in any such given matter. It then maintains the position that the interest of the child is and ought to continue to be the foremost consideration in resolving any such matter.
\end{abstract}




\section{Introduction}

There can be no doubt that whenever a marriage is contracted as between two consenting parties of full age and capacity, they often intend that it does survive through their entire lives. However, it does occur a good number of the times that things fall apart between the parties to the marriage, the centre subsequently becoming incapable of holding between them. In such instances, the legal remedy is usually a petition for divorce or legal separation by either of them. Where there exists an Issue or more of the marriage who have not attained majority, the parties, for reasons of their own, usually maintain opposing claims to custody and parental control, the proceedings becoming ipso facto more protracted and contentious, their hitherto simmering hostilities once again being brought to the fore and taken to a new high. This then leaves the court or tribunal with an even more profound issue to resolve; endorsing a parenting plan to cater for the issue(s) of the marriage. A court ordered parenting plan thus provides a roadmap for catering for the divorced or separated couple's child or children. It addresses such matters as which parent the child will primarily live with, how the children's time will be shared with each parent, schooling and education, daycare, religion or creed of the child or children as the case may be and which parent is to decide in relation thereto, visitation as between the separated couple, physical control of the child, financial responsibility for the child and other important matters. Although the parting couple may on their own agree on a plan, it is much more common to find differences and opposing contentions owing to emotional heat in many instances, with the court having the ultimate jurisdiction to render unto each party his due, after a consideration of their submissions and what in its opinion represents the best interests of the child. According to The Free Dictionary (2015), a Parenting Plan is a written plan for parenting children, made when parents separate, specifying how children will share time with each parent and addressing decision making in the children's important life issues. A court ordered parenting plan plan is thus any such written plan for parenting children, handed down by order of court or agreed on as between the parting couple and judicially endorsed as an order of court, enforceable as it were and appealable as a judgment of the court. We will consider Court Ordered Parenting Plan as it relates to marriages contracted under the Marriage Act in Nigeria and as well as at customary law, explaining the jurisdiction of the relevant courts and their limits on each given divide. It is also to be noted that the issue of court ordered parenting cannot arise independently as sufficient to sustain proceedings in court but only as part of ancillary relief(s) sought in a petition for divorce or where an order of court granting judicial separation is sought in Falobi (1976).

\section{Court Ordered Parenting under the Common Law}

Although marriages in Nigeria, in strict legal sense, must be limited into two compartments of Statutory and Customary Marriage; the latter subsumes Islamic Law. It is pertinent to start off by considering Court Ordered Parenting under the Common 
Law given its hallowed place in the evolution and development of Nigerian Law and as forming part of the Received English Law in Nigeria.

At Common law, just as is the case in Nigeria as judicial precedents are testament to, the foremost particular relief sought and granted vis a vis litigation as to court ordered parenting is the order as to custody of children, with other equally important matters incidentally and consequentially resolved upon it. Under Common law, either the father or mother can get custody of the child depending on the facts of the case. Neither parent is entitled to custody as a matter of course in Re J (2005) a composition of many factors is at play. These include the emotional attachment of the child to a particular parent (father or mother) the adequacy or otherwise of facilities for the child's education with either parent is also considered. Religion and opportunities for proper upbringing of the child are also factors affecting the determination of the Issue as to who should take custody. Custody will usually be awarded to the mother where the child is of very tender year according to Sagay (1990) but the father has an absolute right to decide a child's religious upbringing as expressed by Abdulrazaq (2004). A Child's emotional attachment to a particular parent is equally a compelling consideration as well as the need for the siblings to be brought up together in a conducive home, in the case of more than one child. The child's own wishes or preferences are equally relevant. Generally, a parent's character does not determine whether he or she will be a good parent as custody may be granted to an errant parent or one proven to be adulterous if doing so will best cater for the child's best interests.

\section{Court Ordered Parenting in Statutory Marriages in Nigeria}

We will now consider Court Ordered Parenting as pertaining to marriages contracted within the purview of the Marriage Act (2004). As has been noted elsewhere in this work, a parenting order can only be made by the Court as an ancillary relief in proceedings for judicial separation or divorce in Falobi (1976) so that it must first be shown by a petitioner under this head that the marriage is one under the Act. A Statutory marriage in Nigeria is one shown to have been celebrated before a licensed registrar of marriages in Nigeria or a licensed marriage officer outside Nigeria between a man and woman who must have been previously unmarried in Marriage Act (2004). Now, in making a parenting order under this head, the overriding consideration is the best interests of the Child. This is as provided for in Section 71, Matrimonial Causes Act (2004). The court considers what will be best for the welfare, advancement and education and religious development of the Child. Usually, where the child is still very tender, the mother more will be likely to get custody, with an order being made as to payment of maintenance by the father, the presumption being that the child will be better taken care of by the mother. But this presumption is largely rebuttable and can be impeached if it can be shown for instance that the mother is immoral, has an infectious disease, suffers insanity or is cruel to the child in Odogwu (1992). Thus in Odogwu v Odogwu (1992) a decree of dissolution of marriage was pronounced by the 
court on a petition brought by the husband on grounds of adultery on an appeal to the Supreme Court. It was noted by Belgore (1992) on the considerations in determining the best interests of the children, under Section 71(1) Matrimonial Causes Act, that these matters cannot be quantified in terms of materials as food or money but must of necessity promote the happiness and security that a tender age requires. Fathers asking for custody are equally required to prove that they can personally provide attention, care and nurture in addition to material needs and that they are fit to have custody. A parenting order under this head would usually encompass provisions as to maintenance and welfare of the child.

There is also a preference for awarding custody of male children to the father and female children to the mother but then this is no hard and fast rule. The circumstances of each case determine what the best interest of the child/children. By Section 69 of the Matrimonial Causes Act, 1970, marriage, children of marriages for purposes of custody, maintenance and settlement under the act are; adopted children by either or both Husband and wife, any child born before the marriage (whether legitimated by the marriage or not) and any child (including an illegitimate child of either of them and adopted by either of them) if, at the relevant time, the child was already a member of the Household of the husband and wife. It is noteworthy here that the legitimacy or otherwise of the child as contemplated by the Act here appears inconsistent with the constitutional injunction against the subjection of a citizen of Nigeria to deprivation by reason of the circumstances of his birth under the constitution (1999). To that extent, the provision will be ineffectual under the constitution (1999). Thankfully, the Child Rights Act (2003) has stepped in to offer some reprieve for children who do not come within the purview of the Matrimonial Causes Act and who by reason of that cannot be beneficiary of a parenting plan under the MCA. Section 55 (2004) permits an application to be brought before a family court at the High Court or Magistrate Court on behalf of such children for an order for periodic payment to the children or to the Applicant on behalf of such children or payment of a lump sum in such case. The court can in such instance make an order enforcing a maintenance agreement (2004). As has been noted, a parenting order can only be made by the court seized of jurisdiction as an ancillary relief in a divorce or judicial separation petition. This is the intendment of Section 114 of the Matrimonial Causes Act which requires that a maintenance or custody order must be made in a pending matrimonial cause.

Thus in the case of Ugbah v Ugbah by Adamu (2009) the Court of Appeal held that the suit for maintenance and custody brought by a wife ought to fail for not having been brought as an ancillary relief in a matrimonial cause. The overriding interest of the child as the foremost factor in the grant of parenting orders by the courts cannot be overemphasized. Thus in the case of Theresa Temitayo Williams $v$ Rasheed Ahmed Williams as expressed by Obaseki (1987) the Supreme Court per Obaseki JSC, noted that 'an order for custody must have in view the opportunity for sound education as 
well as physical and mental welfare. A parent who will deny this to his or her child is not worthy of an order of custody from the court. The fact that the mother has custody will not prevent the father from making plans for the infant's education.' The assessment of maintenance allowance in a divorce or separation case is within the discretion of the court. However, a number of guiding principles or factors which guide the court in its assessment include the means or earning capacity, income or assets of either of the parent, their conduct, age of the children and other relevant factors.

\section{Court Ordered Parenting under Customary Cum Islamic Laws}

Given that under our legal system, Islamic Law is regarded as a subset of Customary Law, we will discuss court ordered parenting under the two heads jointly. Now, there is a presumption that all court ordered parenting plans especially as respecting custody will be in favour of the father. For a Marriage to be subject to customary law, the ceremonies for celebrating marriage under that particular system of customary law must be shown to have been complied with and it must be shown that the price was paid. If any of these conditions are shown not to have been met, custody and control of the Child is almost always certainly awarded to the mother. Having said that, there is a presumption that in all customary marriage proceedings, custody of the child or children ought to be awarded to the father, the father being in a privileged position in many Nigerian Cultures but this practice is not uniform throughout the land. Under Yoruba Customary Law, mothers are granted custody of female children and fathers of male children as expressed by mzagans (2015) In Igbo Customary law, Custody can only be in issue as relating to weaned Children and is usually awarded in favour of the Child's father as stated by mzagams (2015) Customary Law in many a clime in Nigeria, gives the father exclusive right over the Children of the Marriage, extending beyond custody of the children to ownership. The Law on court ordered parenting is very composite in Islamic law. Particularly, Schools exist as to Custody of Children under Sharia Law, one of which is known as Hadanah. An overriding principle determining whether a Child will be beneficiary of a court ordered parenting plan under Sharia Law is Legitimacy, unlike under the MCA where an order can be made in favour of a hitherto illegitimate child acknowledged by the parent(s).

Having said that, where parents separate under Islamic Law, custody is granted to the mother but she must first be shown to be of sound mind, trustworthy and of suitable character. She must then be of age and be resident in a place suitable enough to guarantee the Child's moral and physical wellbeing by Abdulrazaq (2004) there is beyond that a permitted cadre of precedence for grant of custody in Islamic Law. Thus where the mother is incapacitated or loses the right owing to her depravity, the maternal relatives have priority over the paternal relatives of the child. In such instance, custody may be awarded to the child's maternal grandmother, the child's maternal aunt or the mother's maternal aunt, in that order. Where the foregoing options are exhausted, custody may then be granted to the child's father, the Child's Sister, where she is of 
age, the child's paternal aunt and the father's maternal aunt. In all such cases where a woman is granted custody, the child's father will have the duty of financially providing for the child's upkeep.

The right of custody may be lost where the grantee becomes terminally ill or converts to a religion other than Islam by A (2004) Special consideration is equally given to the fact of the Child being boy or girl, with the father's relatives favored in respect of the former as stated by L (2004) Another school is the Hanablis, which holds that custody of a female child should be with the mother until she attains seven years of age when she becomes free to choose as between the two parents, who to live with. That of the male child terminates on attainment of the age of nine. There are also the Maliki and Hanaflis Schools, with slightly divergent principles.

\section{Courts with Jurisdiction to Make Parenting Orders}

Jurisdiction is the power and competence of a court to enquire into a dispute or question submitted before it by parties and to hand down a reasoned, binding and enforceable decision in Madukolu (1962). The court with the jurisdiction to make parenting orders in respect of statutory marriages is principally the High Court of a State. This is by virtue of Section 2 of the Matrimonial Causes Act, 1970 and Section 270, Constitution of the Federal Republic of Nigeria, 1999. A Parenting order as to custody or other related matter will be an ancillary relief in a proceeding for dissolution of marriage in the High Court of the State where the respondent resides. In relation to customary marriages, jurisdiction is vested in the Customary Court established by law of the State assembly in the State in question, pursuant to Section 6(6) of the Constitution. A party dissatisfied or aggrieved by a decision of the customary court in granting or refusing any particular order appeals to the Customary Court of Appeal of the State pursuant to the constitution (1999) Parenting orders in proceedings relating to Islamic marriages is within the jurisdiction of the Sharia Courts and Area courts established by law of the State assemblies where they are needed in the constitution (1999) with appeals lying to the Sharia Court of Appeal of the State (1999) It must be noted however, that by virtue of Section 55, Child Rights Act an application may now be brought before a family court in a Magistrate or High Court for grant of relief in the form of an order for payment of maintenance or payment of a lump sum in favour of a child or children of the separated couple of a marriage. It is submitted that this provision ought to be read as expanding the boundaries of jurisdiction of courts to make parenting orders beyond instances where a pending application for dissolution of marriage or judicial separation is subsisting. It establishes, in its capacity as an Act of the National Assembly, a new frontier of jurisdiction of Courts in making parenting orders.

\section{The Never Ending Fight; Reflections and Conclusion}

We have considered the legal aspects of court ordered parenting. The considerations at play in proceedings for custody and related matters are diverse. Many 
a time, the contending parties maintain their claim to custody of children with solely an aim to spite the other. This happens where, for instance, that other parent is especially attached to the child in question. In other instances, the parting parents go to unusual lengths to convince the children of their greater love for them. Allegations of unruly conduct by the adverse party reign. This is seen especially in instances where the child's own preferences will be material to the decision of the court. The parties try to sow discordant tunes in the minds of the children towards the adversary, the differences fuelling their feud being brought afore. The children of the Marriage are not better for it. Regarded as spoils of 'war', the protracted, drawn out proceedings leave telling, indelible marks on their psyche that sometimes live with them throughout the journey of life, especially where they have acquired cognitive dissonance at the time. The solution is in finding a substitute to litigation in ironing out parenting issues in the event of divorce or separation. Mediation, Conciliation or even Arbitration will be safer paths. Litigation in parenting matters is usually akin to a fight, determined to be fought through to the end by the parting, often bitter couple. The adoption of alternative dispute resolution mechanisms such as the fore-listed will make for healthier separation of parting couples. It will in turn ease the adverse effects that the children of the marriage will undoubtedly feel. Given the hallowed place of family in the harmony and continued growth and granted that children are at the very heart of it, their overriding best interests ought to chiefly cardinal and foremost in any decision or determination as to a plan for their effective parenting.

\section{References}

Abdulrazaq, F. F. (2004). Custody of children in Nigeria: A comparative analysis of the relevant laws Benin City: Melthouse Publishers Ltd. p.31

FRN (1999). Section 1(3); Section 42(2); Section 6(6); Sections 262; Sections 267; Section 277 and 282 of the Constitution of the Federal Republic of Nigeria, 1999 (as amended).

FRN (2004). Marriage Act Cap M6: Laws of the Federation of Nigeria; Cap M7, Laws of the Federation of Nigeria, 2004; Cap C22 Laws of the Federation of Nigeria, 2004.

Legal dictionary (2015). Parenting issues. Accessed 12:10pm, 13/11/2015 from www.legaldictionary.net/parentingissues,

Sagay, I. (1990). Modern Nigerian family law. Benin City: Malthouse Press Ltd. p.20

Supreme Court of Nigeria (1976). See the Observations of the Supreme Court per Fatayi-Wlilliams; JSC in Falobi v Falobi, 1976, Suit No SC 112/1975 p.65; 
AFRREV, 10 (1), S/NO 40, JANUARY, 2016

See the Observations of Baroness Hale of Richmond In the House of Lords' case of Re: J( a Child) 2005, UKHL 40

Wordpress.com (2015). Child Custody in Nigeria. Accessed 10:45PM 16/11/2015 from mzagams.wordpress.com

(2009) 3 NWLR pt 1127, pg 108, per Adamu JCA p.108

1987 All NLR, 253. Rev. Obaseki JSC P.121

Falobi's Case, supra p.66

Madukolu v Nkemdilim (1962) SCNLRP 341.

Odogwu v Odogwu (1992) 2 NWLR, pt 225, pg 539.

Per Belgore JSC (as he then was) 